\title{
Effects of Lead on the Induction of Hepatic Microsomal Enzymes by Phenobarbital and 3,4-Benzpyrene ${ }^{1,2}$
}

\author{
C. P. $\mathrm{CHOW}^{3}$ AND H.- H. CORNISH \\ Interdepartmental Toxicology Program and Department of Environmental and Industrial Health, \\ The University of Michigan, Ann Arbor, Michigan 48109
}

Received November 26, 1976; accepted July 8, 1977

\begin{abstract}
Effects of Lead on the Induction of Hepatic Microsomal Enzymes by Phenobarbital and 3,4Benzpyrene. Chow, C. P. And Cornish, H. H. (1978). Toxicol. Appl. Pharmacol. 43, 219-228. A single ip injection of lead acetate $(65 \mathrm{mg} / \mathrm{kg})$ prolonged the duration of zoxazolamine paralysis in Sprague-Dawley rats and prevented the stimulation of zoxazolamine metabolism normally induced by phenobarbital. Lead also delayed the phenobarbital induction of hepatic microsomal cytochrome $P-450$ at 12 and $24 \mathrm{hr}$ after treatment. However, the inhibitory effect of lead had disappeared and cytochrome $P-450$ concentrations were markedly elevated at 48 hr. Lead also diminished hepatic microsomal cytochrome $P-448$, normally resulting from benzyprene treatment. Neither lead, phenobarbital, benzyprene nor their combination had a significant effect on hepatic cytochrome $b_{5}$ values. Lead, in vitro, inhibited the hepatic microsomal NADPH-cytochrome $c$ and $P-450$ reductase activity in a dose-dependent manner. In vivo, significant inhibition of NADPH-cytochrome $c$ and $P-450$ reductase activity was observed after the injection of lead acetate. Significant inhibition coincides with the time when lead concentration in the hepatic microsomes was maximal. The inhibition of $\delta$-aminolevulinic acid dehydratase (ALAD) activity at several blood lead concentrations was confirmed both in vivo and in vitro. This relationship between blood lead concentrations and ALAD activity was not altered by pretreatment with phenobarbital or benzpyrene.
\end{abstract}

Alvares et al. (1972) demonstrated that lead chloride was effective in prolonging hexobarbital sleeping time, decreasing hepatic cytochrome $P-450$ content, and inhibiting in vitro hydroxylase and demethylase activities $24 \mathrm{hr}$ after a single iv injection in the rat. Similar data was obtained by Scoppa et al. (1973), who also observed that the inhibitory effects of lead were dose dependent. Previous studies in this laboratory (Egan and Cornish, 1973) showed that administration of a single dose (100 mg/kg ip) of lead acetate in the rat resulted in a $50 \%$ decrease in hepatic cytochrome $P-450$ values by Day 3 post-treatment, a return to control values by Day 7 , and a near doubling of the cytochrome $P-450$ levels during Days $10-14$. Liver cytochrome $P-450$ values then returned to normal by Day 17 following treatment.

1 This investigation was supported by EPA Grant R-802762-01.

2 Presented at the 14th Annual Meeting of the Society of Toxicology, Wiliamsburg, Virginia, March 1975.

${ }^{3}$ Present address: Drug Toxicology Division, Health Protection Branch, Department of National Health and Welfare, Ottawa, Canada.

"To whom correspondence should be sent at the Department of Environmental and Industrial Health, School of Public Health II, Room M7525, The University of Michigan, Ann Arbor, Michigan 48109. 
Recently, Pani et al. (1975) reported that lead nitrate pretreatment exerted a significant protective effect on rats subsequently poisoned with carbon tetrachloride. The importance of such metabolic interactions among environmental chemicals and drugs has been reviewed by Conney and Burns (1972). Lead is ubiquitous in the environment and may be of special significance if lead also alters the induction of the hepatic microsome drug-metabolizing enzymes. The objectives of the present investigation were twofold: to study the effect of lead on the induction of hepatic microsomal enzymes by phenobarbital and benzpyrene, and to gain further insight into the mechanism by which lead apparently inhibits drug metabolism.

\section{METHODS}

Male, Sprague-Dawley rats ${ }^{5}$ with an average body weight of $200 \mathrm{~g}$ were used in the present study. The animals were allowed 5 days to acclimate to the laboratory environment. Rats were maintained in a temperature-controlled room $\left(25^{\circ} \mathrm{C}\right)$ illuminated from 8 AM to 8 PM. The animals were pair-housed in stainless steel cages with water and Rockland rat chow available ad libitum, but were fasted $24 \mathrm{hr}$ prior to sacrifice.

Duration of zoxazolamine paralysis. Rats were randomly divided into four groups with an average of six rats per group. The first group was pretreated with lead acetate $(65 \mathrm{mg} / \mathrm{kg})$ ip, the second group received phenobarbital $(40 \mathrm{mg} / \mathrm{kg})$ ip, the third group received both lead acetate and phenobarbital, and the control group received equimolar sodium acetate ip injections. In another similar experiment, one group of rats was given lead acetate $(65 \mathrm{mg} / \mathrm{kg})$ and corn oil ip. A second group received benzpyrene $(20 \mathrm{mg} / \mathrm{kg}$ in corn oil) ip. A third group received benzpyrene $(20 \mathrm{mg} / \mathrm{kg}$ in corn oil) and sodium acetate; the fourth group received both lead acetate and benzpyrene. Control rats received an equivalent amount of sodium acetate and corn oil ip. Rats were given water but were deprived of food for the subsequent $24 \mathrm{hr}$ after dosing and prior to the administration of zoxazolamine. Zoxazolamine (neutralized in $0.2 \mathrm{~N} \mathrm{HCl}$ ) was injected ip at a dosage of $100 \mathrm{mg} / \mathrm{kg}$. The time at which each rat lost or regained its righting reflex was recorded. The time at which the rat was able to right itself twice in succession was considered as the end point.

Preparation of microsomes and enzyme assays. Rats were divided at random into four groups (four to six per group) and were treated in a manner identical to that described above but without zoxazolamine treatment. The animals were sacrificed 12,24 , and 48 hr after injections. Rats were anesthetized with USP ether and blood was drawn by open-chest cardiac puncture. The livers were perfused in situ with ice-cold saline and immediately removed. After rinsing in ice-cold $1.15 \%$ potassium chloride, the livers were blotted dry and weighed. All subsequent steps in preparing microsomes were performed with tissue kept at $0-4^{\circ} \mathrm{C}$. Livers were minced with scissors and homogenized individually in $1.15 \%$ potassium chloride in $50 \mathrm{~mm}$ Tris buffer, $\mathrm{pH} 7.4$. The homogenates were centrifuged in a refrigerated Sorvall for $20 \mathrm{~min}$ at $12,500 \mathrm{~g}$. Supernatants were then recentrifuged at $104,000 \mathrm{~g}$ for $90 \mathrm{~min}$ in a Beckman ultracentrifuge. The microsomal pellets were washed with a small volume of $0.1 \mathrm{M} \mathrm{Hepes}^{6}$

\footnotetext{
${ }^{5}$ Spartan Research Animals, Inc., Haslett, Michigan.

${ }^{6} \mathrm{~N}$-2-Hydroxyethylpiperazine $N^{\prime}$-2-ethanesulfonic acid, Sigma Chemical Co., St. Louis, Missouri.
} 
buffer, pH 7.4. The washed microsomes were then resuspended in the same buffer such that the resulting suspension contained approximately $10 \mathrm{mg}$ of protein/ml. Protein concentration was determined by the method of Lowry et al. (1951), with bovine serum albumin as the standard.

Measurements of microsomal cytochromes $P-450$ and $b_{5}$ were made following the methods of Omura and Sato (1964). Cytochrome $P-450$ was determined from the CO difference spectra of dithionite-reduced microsomes between 450 and $490 \mathrm{~nm}$ in an Aminco DW-2 spectrophotometer. Cytochrome $b_{5}$ content in the microsomal preparation was estimated from the reduced nicotinamide adenine dinucleotide (NADH) difference spectra at 409 to $424 \mathrm{~nm}$.

NADPH-Cytochrome $c$ reductase activity was measured by determining the rate of increase in absorbance at $55.0 \mathrm{~nm}$ produced by the reduction of cytochrome $c$. Each cuvette of $1-\mathrm{cm}$ light path contained $1 \mu \mathrm{mol}$ of sodium cyanide, $0.1 \mu \mathrm{mol}$ of cytochrome $c, 0.2 \mathrm{mg}$ of microsomal protein, and sufficient $0.1 \mathrm{~m}$ Hepes buffer, $\mathrm{pH} 7.4$, to adjust to $3.0 \mathrm{ml} ; 0.4 \mu \mathrm{mol}$ of NADPH was added to the sample cuvette to start the reaction. The rate of cytochrome $c$ reduction was followed at $25^{\circ} \mathrm{C}$. The first 1 -min linear segment of the reduction slope was used to calculate enzyme activity.

NADPH-Cytochrome $P-450$ reductase was measured as described by Fouts and Devereux (1972) in an Aminco-Morrow stopped-flow apparatus connected to an Aminco DW-3 recording spectrophotometer in the dual-wavelength mode at 450 and $490 \mathrm{~nm}$. The first 1-sec segment of the reaction slope was used to calculate enzyme activity.

Erythrocyte $\delta$-aminolevulinic acid dehydratase ( $\delta$-ALAD) activity was determined according to the procedure described for human blood (Burch and Siegel, 1971).

Estimation of blood lead concentration was routinely done with the Delves sampling cup (Fernandex et al., 1973), and was occasionally checked by the method of Yaeger $e t$ al. (1971). Determination of lead in liver was done by the method of Yaeger et al. (1971). Hepatic microsomal lead concentration was analyzed with the sampling boat system (Kahn and Sebestyen, 1970). A Perkin-Elmer Model 403 atomic absorption spectrometer with recorder, a three-slot burner head, a hollow-cathode lamp, and, at times, a deuterium background corrector were used for the above work.

Statistical methods. The statistical significance between test and control groups was determined by Student's $t$ test (Burlington and May, 1953). The difference between means was considered significant when $p<0.05$. Results are expressed as the means \pm SE.

\section{RESULTS}

Effects of Lead on the Stimulation of Zoxazolamine Metabolism after Phenobarbital or Benzpyrene Pretreatments

A single ip injection of lead acetate $(65 \mathrm{mg} / \mathrm{kg})$ significantly prolongs the duration of zoxazolamine paralysis (Table 1), presumably by inhibiting its metabolism to 6hydroxyzoxazolamine by the hepatic microsomal enzymes (Conney et al., 1960). Both phenobarbital and benzpyrene pretreatments significantly reduced zoxazolamine paralysis time. In rats treated with lead and phenobarbital zoxazolamine paralysis time was nearly the same as in lead-treated animals, while in the lead plus benzypyrene-treated animals the paralysis time was comparable to that seen in rats treated 
TABLE 1

Duration of ZoXazolamine Paralysis in Rats following Treatment with Lead, Phenobarbital, AND BENZPYRENE

\begin{tabular}{lc}
\hline \multicolumn{1}{c}{ Treatment (ip) } & $\begin{array}{c}\text { Duration } \\
(\mathrm{min})^{a}\end{array}$ \\
\hline A. Sodium acetate & $248.6 \pm 25.5$ \\
B. Lead acetate $(65 \mathrm{mg} / \mathrm{kg})$ & $377.8 \pm 28.0^{b}$ \\
C. Phenobarbital $(40 \mathrm{mg} / \mathrm{kg})$ & $99.5 \pm 5.1^{b}$ \\
D. Phenobarbital + lead acetate & $268.5 \pm 27.9^{c}$ \\
E. Corn oil & $235.2 \pm 24.4$ \\
F. Lead acetate $(65 \mathrm{mg} / \mathrm{kg})$ & $335.2 \pm 30.5^{d}$ \\
G. Benzypyrene $(20 \mathrm{mg} / \mathrm{kg})$ & $20.0 \pm 1.1^{d}$ \\
H. Benzpyrene + lead acetate & $21.8 \pm 1.6^{d}$ \\
\hline
\end{tabular}

\footnotetext{
${ }^{a}$ Mean \pm SE.

${ }^{b}$ Significantly different from A $(p<0.05)$.

${ }^{c}$ Significantly different from $\mathrm{C}(p<0.05)$.

${ }^{a}$ Significantly different from $\mathrm{E}(p<0.05)$.
}

with benzypyrene alone. Thus, lead appeared to be effective in preventing the stimulation of zoxazolamine metabolism produced by phenobarbital, but had no effect on the stimulation of zoxazolamine metabolism produced by benzpyrene.

Effect of Lead on the Induction of Hepatic Microsomal Cytochromes P-450,P-448, and $b_{5}$ by Phenobarbital or Benzpyrene

Figure 1 shows that a single ip injection of lead acetate $(65 \mathrm{mg} / \mathrm{kg})$ significantly reduced hepatic microsomal cytochrome $P-450$ at $24 \mathrm{hr}$. Lead was also found to delay the phenobarbital $(40 \mathrm{mg} / \mathrm{kg})$ induction of cytochrome $P-450$ normally seen at 12 and $24 \mathrm{hr}$ after phenobarbital treatment. However, the inhibitory effect of lead disappeared

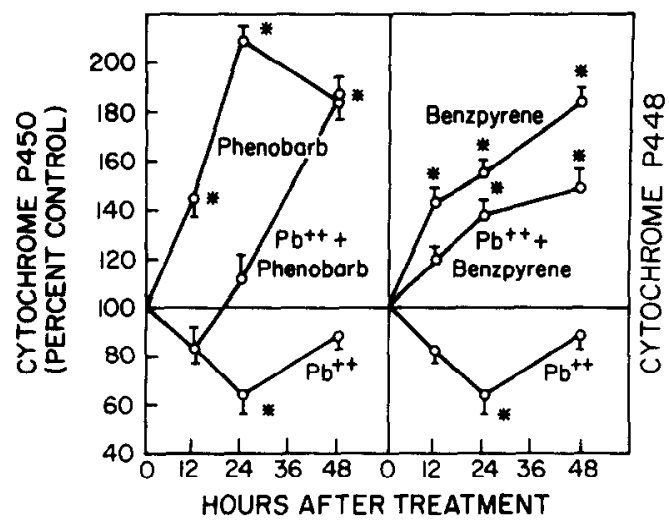

FIG. 1. Hepatic microsomal cytochrome $P-450$ or $P-448$ content after ip administration of lead acetate $(65 \mathrm{mg} / \mathrm{kg})$, phenobarbital $(40 \mathrm{mg} / \mathrm{kg}$ ), and $/$ or $3,4-$ benzypyrene $(20 \mathrm{mg} / \mathrm{kg})$. Control rats received an equivalent amount of corn oil and/or sodium acetate. The average control (100\%) cytochrome $P-450$ concentration was $0.565 \pm 0.017 \mathrm{nmol} / \mathrm{mg}$ of protein $(*, p<0.05)$. 
and cytochrome $P-450$ was markedly elevated $48 \mathrm{hr}$ after phenobarbital dosing. Lead was also capable of diminishing the induction of hepatic microsomal cytochrome $P$-448 (Fig. 1) during the first $48 \mathrm{hr}$ after the ip administration of benzypyrene $(20 \mathrm{mg} / \mathrm{kg})$.

Neither lead, phenobarbital, benzpyrene, nor their combinations had any significant effect on hepatic microsomal cytochrome $b_{s}$ during the $48 \mathrm{hr}$ subsequent to their injections.

Effect of Lead on Hepatic Microsomal NADPH-Cytochrome c Reductase after Phenobarbital or Benzpyrene

Lead acetate $(65 \mathrm{mg} / \mathrm{kg})$ significantly inhibited the hepatic microsomal NADPHcytochrome $c$ reductase activity $24 \mathrm{hr}$ after a single ip injection (Fig. 2). The enzyme activity induced by phenobarbital was also markedly inhibited during the 48 -hr period

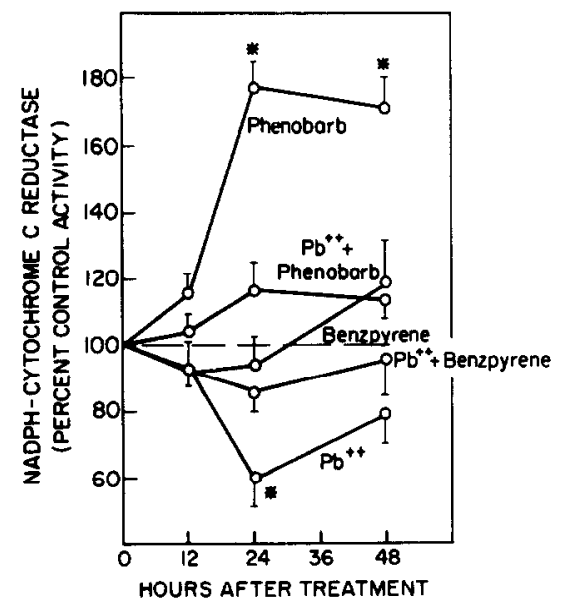

FIG. 2. Hepatic microsomal NADPH-cytochrome $c$ reductase activity after an ip injection of lead acetate $(65 \mathrm{mg} / \mathrm{kg})$, phenobarbital $(40 \mathrm{mg} / \mathrm{kg})$, and $/$ or 3,4 -benzpyrene $(20 \mathrm{mg} / \mathrm{kg})$. Control rats received an equivalent amount of corn oil and/or sodium acetate. The average control activity was $32.46 \pm 2.47 \mathrm{nmol}$ of cytochrome $c$ reduced $/ \mathrm{min} / \mathrm{mg}$ of protein $(*, p<0.05)$.

after lead injection. Neither benzpyrene nor benzpyrene plus lead exerted a significant effect on this enzyme activity in vivo even though lead alone resulted in approximately a $40 \%$ inhibition.

Effect of Lead on Hepatic Microsomal NADPH-Cytochrome P-450 Reductase after Phenobarbital or Benzpyrene

Lead acetate $(65 \mathrm{mg} / \mathrm{kg})$ had a significant inhibitory effect on the hepatic microsomal NADPH-cytochrome $P-450$ reductase activity $24 \mathrm{hr}$ after an up injection (Fig. 3). Lead was also found to inhibit markedly the NADPH-cytochrome $P$-450 reductase activity induced by phenobarbital at 12 and $24 \mathrm{hr}$. However, by $48 \mathrm{hr}$ the inhibitory effect of lead had partially disappeared and the induction of NADPH-cytochrome $P-450$ reductase by phenobarbital became significant. Neither benzpyrene nor benzpyrene plus lead had any significant effect on the NADPH-cytochrome $P-450$ reductase activity when compared with the control group. 


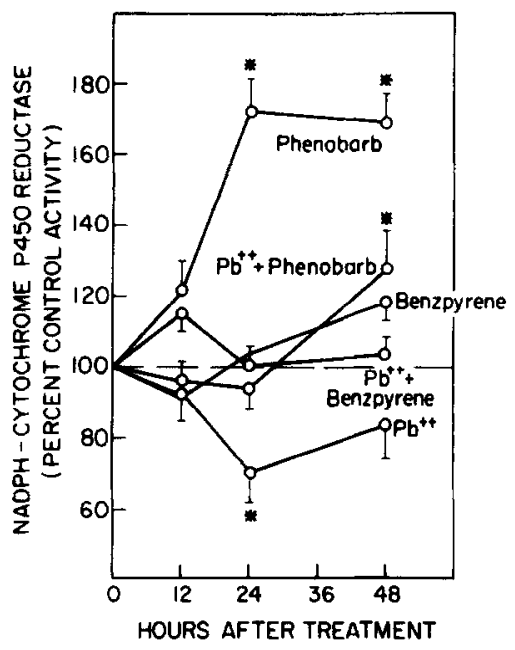

FIG. 3. Hepatic microsomal NADPH-cytochrome $P-450$ reductase activity after an ip injection of lead acetate $(65 \mathrm{mg} / \mathrm{kg})$, phenobarbital $(40 \mathrm{mg} / \mathrm{kg})$, and $/$ or 3,4-benzpyrene $(20 \mathrm{mg} / \mathrm{kg})$. The average control activity was $0.0049 \pm 0.0002$ units $/ \mathrm{sec} / \mathrm{mg}$ of protein. $(*, p<0.05)$.

Effect of Lead on the Hepatic Microsomal NADPH-Cytochrome $c$ and P-450 Reductase Activities in Vitro

When lead was added to the hepatic microsomes from control rats, the percentage of inhibition of NADPH-cytochrome $c$ and $P-450$ reductase activities was found to be a linear function of the logarithm of lead concentration. The concentration of lead required to inhibit $50 \%$ of the enzyme activity (I50) was approximately $0.53 \mathrm{~mm}$ for NADPH-cytochrome $c$ reductase and $0.63 \mathrm{mM}$ for NADPH-cytochrome $P-450$ reductase (Fig. 4).

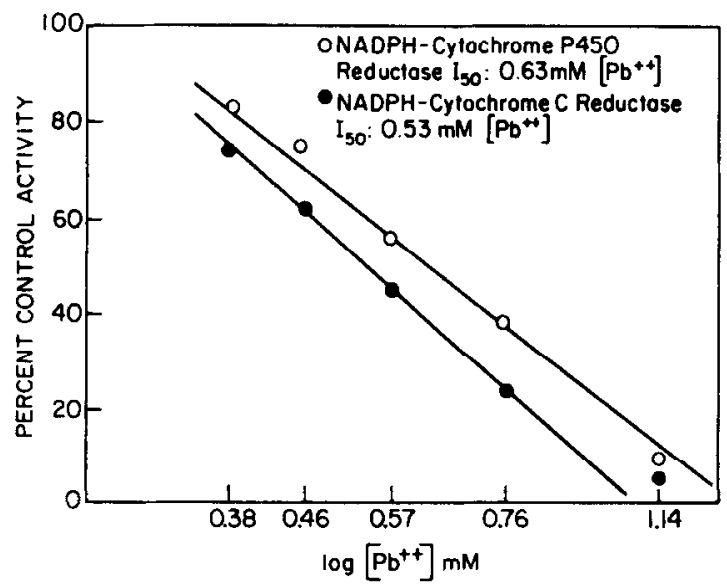

FIG. 4. In vitro effect of lead on the NADPH-cytochrome $c$ and $P-450$ reductase activity in rat liver microsomes. 


\section{Effect of Lead on Erythrocyte $\delta-A L A D$ Activity in Vitro and in Vivo}

Lead inhibition of rat erythrocyte $\delta$-ALAD activity was shown to be dose dependent in vitro (Fig. 5). The $\mathrm{I} 50$ value for this enzyme was $0.82 \mu \mathrm{M}\left[\mathrm{Pb}^{2+}\right]$. Erythrocyte $\delta$ ALAD activity was approximately $40 \%$ inhibited 12 to $24 \mathrm{hr}$ after a single lead acetate

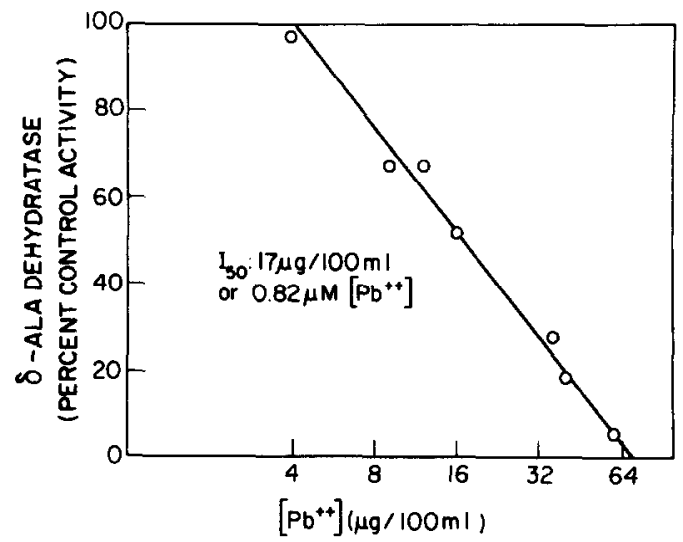

FIG. 5. In vitro effect of lead on rat erythrocyte $\delta$-aminolevulinic acid dehydratase activity.

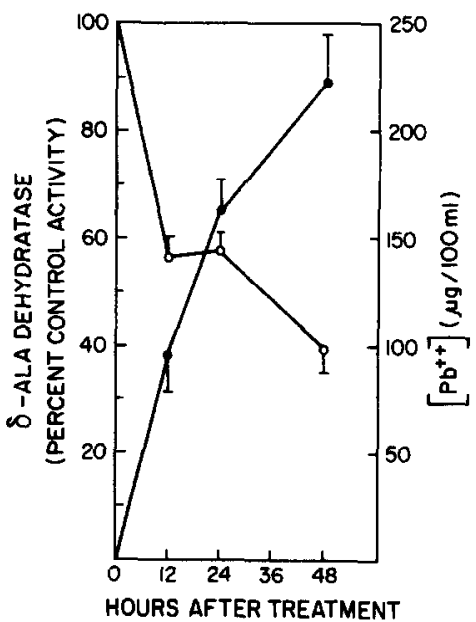

FIG. 6. Inhibition of rat erythrocyte $\delta$-aminolevulinic acid dehydratase activity (open circles) and blood lead concentrations (filled circles) after lead acetate $(65 \mathrm{mg} / \mathrm{kg}$ ip).

injection $(65 \mathrm{mg} / \mathrm{kg}$ ip) and $60 \%$ inhibited at $48 \mathrm{hr}$ when blood lead concentration was approximately $220 \mu \mathrm{g} / 100 \mathrm{ml}$ (Fig. 6). Neither phenobarbital $(40 \mathrm{mg} / \mathrm{kg}$ ) nor 3,4benzpyrene $(20 \mathrm{mg} / \mathrm{kg})$ had an effect on this enzyme activity in either control or leadtreated rats.

\section{Liver and Microsomal Lead Levels}

Figure 7 shows that lead concentration in rat whole liver was higher at $48 \mathrm{hr}$ than at $24 \mathrm{hr}$ after a single ip injection of lead acetate $(65 \mathrm{mg} / \mathrm{kg})$. Conversely, lead bound to the isolated microsomal fraction was considerably higher $(115 \mu \mathrm{g} / \mathrm{g}$ of microsomal 


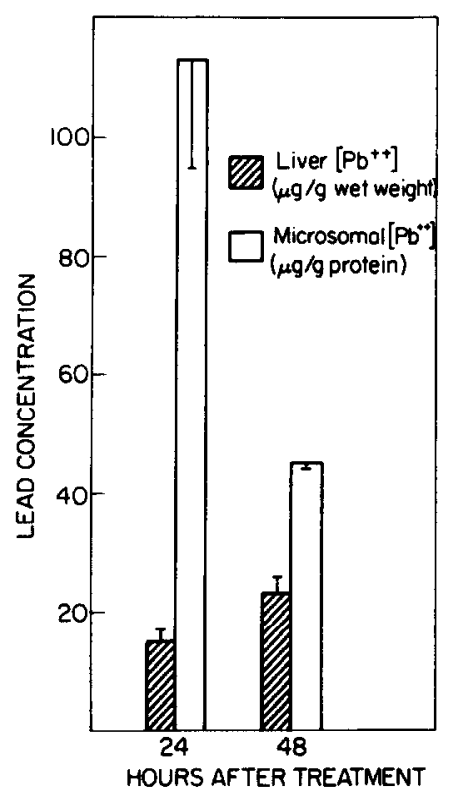

Fig. 7. Lead concentration in whole liver and liver microsomes of rats treated with lead acetate $(65$ $\mathrm{mg} / \mathrm{kg}$ ip).

protein) $24 \mathrm{hr}$ after the ip injection of lead acetate than at $48 \mathrm{hr}(45 \mu \mathrm{g} / \mathrm{g}$ of microsomal protein).

\section{DISCUSSION}

A single ip injection of lead acetate depressed cytechrome $P-450$ values and delayed the induction of hepatic microsomal cytochrome $P-450$ by phenobarbital. Norpoth et al. (1974) had reported that a daily dose (po) of $30 \mathrm{mg}$ of lead acetate for 4 days failed to inhibit the induction of hepatic cytochrome $P-450$ by phenobarbital. These two findings are not incompatible since the inhibitory effects of lead on hepatic microsomal enzymes were found to be transient and time dependent.

Master et al. (1973) reported reduced activity of both NADPH-cytochrome $c$ and $P$ 450 reductase activities by the antibody to NADPH-cytochrome $c$ reductase. This evidence suggested that hepatic microsomal NADPH-cytochrome $c$ and $P-450$ reductases are closely related or are the same protein. In the present study the effects of lead on hepatic microsomal NADPH-cytochrome $c$ and $P-450$ reductase activities (Figs. 2-4) were remarkably similar, consistent with such a hypothesis. Neither lead, phenobarbital, benzpyrene, nor their combination had an effect on hepatic microsomal cytochrome $b_{3}$ during the 48 -hr period of this study. This may be due to the relative slow turnover rate (half-life: 4 or 5 days), of this heme-protein (Kuriyama et al., 1969).

The duration of zoxazolamine paralysis reflects hepatic microsomal hydroxylase activity (Conney et al., 1960). In this study the prolonged zoxazolamine paralysis resulting from lead ingestion correlates well with the depressed hepatic microsomal cytochrome $P-450$ or $P-448$ concentrations (Fig. 1). These findings support the 
hypothesis of Scoppa et al. (1973), who proposed that lead inhibits drug metabolism via inhibition of heme synthesis and decreases the availability of hepatic cytochrome $P-450$. The relatively short half-life ( $22 \mathrm{hr}$ ) of cytochrome $P-450$ in the liver is consistent with such a mode of action (Greim et al., 1970). Table 1 shows that the duration of zoxazolamine paralysis in rats treated with the combination of lead and phenobarbital was comparable to controls and significantly different from those treated with phenobarbital alone. However, rats treated with lead and benzpyrene had about the same duration of zoxazolamine paralysis as rats treated with benzpyrene only. It is noteworthy that the cytochrome $P-450$ concentrations in rats treated with lead and phenobarbital are similar to those of controls at $24 \mathrm{hr}$. However, the cytochrome $P-448$ values in rats injected with blood and benzpyrene are much elevated compared with those of controls at $24 \mathrm{hr}$ (Fig. 1). Thus the cytochrome $P-450$ or $P-448$ concentrations in all groups are reasonably consistent with the observed paralysis times. Conney et al. (1960) had reported that the zoxazolamine hydroxylase activity in rat liver microsomes was stimulated more quickly by benzpyrene than by phenobarbital. This is not apparent in the present cytochrome $P-450$ or $P-448$ data 12 or $24 \mathrm{hr}$ after treatment (Fig. 1), even though benzpyrene treatment resulted in a considerably shorter paralysis time than did phenobarbital when measured $24 \mathrm{hr}$ after treatment.

Scoppa et al. (1973) further proposed that binding of lead to the sulfhydryl groups in the mixed function oxidase enzyme system was not responsible for the impairment of drug metabolism in acute lead poisoning because lead was ineffective when added to the incubation mixture of the in vitro hydroxylase or demethylase assays. Preliminary studies in this laboratory also showed that in vitro lead had no marked effects on the hepatic microsomal NADPH-cytochrome $c$ and $P-450$ reductase activities. The phosphate buffer used in these assays apparently complexed with lead and decreased lead ion concentration at the enzymatic sites since the inhibitory effects of lead were evident when a Hepes buffer was used. This buffer does not readily form complexes with most metals (Good et al., 1966). The concentrations of lead ions generally required to inhibit sulfhydryl enzymes in vitro ranges from 0.1 to $1.0 \mathrm{~mm}$ (Vallee and Ulmer, 1972). In the present study lead concentrations in whole liver $(18 \mu \mathrm{g} / \mathrm{g}$ of liver) were approaching $0.1 \mu \mathrm{mol} / \mathrm{g}$ of liver $24 \mathrm{hr}$ after a single ip injection of lead acetate (65 $\mathrm{mg} / \mathrm{kg}$ ). At this time the lead concentration in isolated hepatic microsomes was 0.55 $\mu \mathrm{mol}$ of $\mathrm{Pb} / \mathrm{g}$ of microsomal protein indicating a considerable concentration in this subcellular fraction. NADPH-Cytochrome $c$ and $P-450$ reductases, which contain functional sulfhydryl groups (Williams and Kamin, 1962), were 30 to $40 \%$ inhibited at this time. The in vitro study (Fig. 4) showed that the 150 values for the inhibition of NADPH-cytochrome $c$ and $P-450$ reductases by lead were 0.53 and $0.63 \mathrm{~mm}$, respectively. Thus there is reasonable agreement between the in vivo and in vitro inhibition of the hepatic microsomal NADPH-cytochrome $c$ and P-450 reductase activities by lead although the amount of lead bound to microsomes was not measured in the in vitro study. The combined data demonstrated that, on an acute experimental basis, microsomal enzyme activites are inhibited in vivo at lead concentrations consistent with those that produce inhibition when studied in vitro. Direct binding of lead to the sulfhydryl groups of the NADPH-cytochrome $c$ and $P-450$ reductases may be an important factor in the impairment of hepatic drug metabolism resulting from acute lead exposure. 


\section{REFERENCES}

Alvares, A. P., Leigh, S., Cohn, J., And Kappas, A. (1972). Lead and methyl mercury: Effects of acute exposure on cytochrome $P-450$ and the mixed function oxidase system in the liver. J. Exp. Med. 135, 1406-1409.

BURCH, H. B., AND SIEGEL, A. L. (1971). Improved method for measurement of delta-aminolevulinic acid dehydratase activity in human erythrocytes. Clin. Chem. 17, 1038-1041.

Burlington, R. S., and May, D. C. (1953). Handbook of Probability and Statistics. Handbook, Sandusky, Ohio.

Conney, A. H., Trousof, N., AND Burns, J. J. (1960). The metabolic fate of zoxazolamine in man. J. Pharmacol. Exp. Ther. 128, 333-339.

CONNEY, A. H., AND BURNS, J. J. (1972). Metabolic interactions among environment chemicals and drugs. Science 178, 576-586.

EgAN, G. F., AND CoRnish, H. H. (1973). The effects of lead on rat liver cytochrome P-450. Toxicol. Appl. Pharmacol. 25, 467.

FERNANDEZ, F. J. (1973). Some observations of the determination of lead in blood with the Delves cup method. At. Absorption Newslett. 12, 70-72.

Fouts, J. R., AND DevereuX, T. R. (1972). Developmental aspects of hepatic and extrahepatic drug metabolizing enzymes. J. Pharmacol. Exp. Ther. 183, 458-468.

Good, N. E., Winget, G. D., Winter, W., Connolly, T. N., Izawa, S., and Singh, R. M. M. (1966). Hydrogen ion buffers for biological research. Biochemistry 5, 467-477.

Greim, H., Schenkman, J. B., Klotzbucher, M., and Remmer, H. (1970). The influence of phenobarbital on the turnover of heptic microsomal cytochrome $b_{5}$ and $P-450$ hemes in the rat. Biochem. Biophys. Acta 201, 20-25.

KahN, H. L., AND Sebestyen, J. S. (1970). The determination of lead in blood and urine by automatic absorption spectrophotometry, with the sampling boat system. At. Absorption Newslett. 9, 33-38.

Kuriyama, Y., Omura, T., Siekevitz, P., Palade, G. E. (1969). Effects of phenobarbital on the synthesis and degradation of the protein components of rat liver microsomal membranes. J. Biol. Chem. 244, 2017-2026.

Lowry, O. H., Rosebrough, N. J., Farr, A. L., and Randall, R. J. (1951). Protein determination with the Folin phenol reagent. J. Biol. Chem. 193, 265-275.

Master, B. S. S., Nelson, E. B., Schachter, B. A., Baron, J., AND IsaAcson, E. L. (1973). NADPH-Cytochrome $c$ reductase and its role in microsomal cytochrome $P$-450 dependent reactions. Drug Metabol. Dispos. 1, 121-128.

NoRPOTH, K., Ho, S., AND WITTING, U. (1974). Induction of microsomal hemoproteins in the liver of rats after ingestion of inorganic lead compounds. Int. Arch. Arbeitsmed. 33, 139-151.

OMURA, T., AND SATO, R. (1964). The carbon monoxide-binding pigment of liver microsomes I. Evidence for its hemoprotein nature. J. Biol. Chem. 239, 2370-2378.

Pani, P., Corongiu, F. P., Sanna, A., and Congiv, L. (1975). Protection by lead nitrate against carbon tetrachloride hepatotoxicity. Drug Metabol. Dispos. 3, 148-154.

Scoppa, P., Roumengous, M., AND Penning, W. (1973). Hepatic drug metabolizing activity in lead-poisoned rats. Experientia 29, 970-972.

VALLEE, B. L., AND ULMER, D. D. (1972). Biochemical effects of mercury, cadmium and lead. Annu. Rev. Biochem. 41, 91-128.

Williams, C. H., JR., AND Kamin, H. (1962). Microsomal triphosphopyridine nucleotide cytochrome $c$ reductase of liver. J. Biol. Chem. 237, 587-595.

Yeager, D. W., Cholak, J., and Henderson, E. W. (1971). Determination of lead in biological and related material by atomic absorption spectrophotometry. Environ. Sci. Technol. 5, 1020-1022. 